\title{
Exchange Rate Fluctuations and the Balance of Payments: Channels of Interaction in Developing and Developed Countries
}

\author{
Magda Kandil \\ International Monetary Fund
}

\begin{abstract}
Agents engage in a process of forecasting the exchange rate based on observations of macroeconomic fundamentals. Deviations in the realized exchange rate from agents' forecasts determine fluctuations in components of the current and financial accounts of the balance of payments in a sample of developing and industrial countries. Absent measures to stimulate export growth in developing countries and given their high dependency on imports, the current account balance deteriorates with respect to currency depreciation. Across industrial countries, the reduction in the value of exports with respect to currency depreciation correlates with a reduction in the value of imports. The combined effect cancel out on the trade and current account balances in industrial countries. Similarly, currency appreciation increases the nominal value of exports and imports without a significant effect on the current account balance in industrial countries. The combined evidence highlights the benefits of a flexible exchange rate system, prevailing in many industrial countries, to ensure that a depreciating rate curbs import growth and increases financial flows. In contrast, currency appreciation increases imports and deteriorates the current account balance across developing countries. Moreover, the evidence indicates the adverse effect of an overvalued exchange rate and the expected deterioration in the balance of payments should developing countries be forced to abandon a peg abruptly.
\end{abstract}

- JEL Classification : E31, F41, F43

\footnotetext{
*Corresponding address: Magda Kandil: International Monetary Fund(IMF), Washington B.C. 20431, USA, e-mail: MKANDIL@imf.org (C2009-Center for International Economics, Sejong Institution, Sejong University, All Rights Reserved.
} 
- Key Words: exchange rate, anticipated vs. unanticipated fluctuations, external exposure, economic activity, supply vs. demand channels

\section{Introduction}

Recent episodes of currency crises have focused attention on the importance of exchange rate fluctua-tions and the appropriate exchange rate policy. The 1990s were the years of currency turmoil, characterized by the near breakdown of the European Exchange Rate Mechanism in 1992-93, the Latin American tequila crisis following Mexico's peso devaluation in 1994-95, and the severe crises that swept through Asia in 1997-98. Exchange rate fluctuations are likely to determine economic performance. Industrial and develop-ing countries have had varying experiences with fluctuations in the current and financial account balances. What factors determine these fluctuations over time? More specifically, what are the effects of exchange rate fluctuations, anticipated and unanticipated, on the cyclicality of the current account balance?

As cyclical factors seem to have a major impact on the balance of payments, it seems worthwhile analyzing the effect of these variables in a more systematic way. The traditional approach has focused on the current account deficit and the adequacy of reserves to finance imports. However, the financial account (formerly capital account ${ }^{1}$ ) as the complement of the current account in the accounting relationship in the balance of payments has often been missing from the analysis. In addition, the growing trend to liberalize the financial account has necessitated an analysis of its cyclicality as well. It is, therefore, necessary to study the impact of domestic and external forces, not only on the current account, but also on the financial account, which has been instrumental in financing or even driving a country's large current account deficit. In many cases, the ability of a country to sustain large current account balances has turned on the willingness of foreign investors to place substantial investment funds in the country (see Arrora, Dunaway and Faruquee, 2001, Cooper, 2001, and McKinnon 2001). ${ }^{2}$

Kandil and Greene (2002) analyze the cyclical effects of the balance of

\footnotetext{
${ }^{1}$ Since the redefinition, the capital account now incorporates transactions such as debt forgiveness or one time migrant's transfers (not remittances), see for the exact details of the re-designations the Balance of Payments Manual issued by the International Monetary Fund (IMF, 1993). Since the capital account in the current definition is of no major economic significance in industrial countries, it will be disregarded in the following.

${ }^{2}$ This discussion is ongoing in prominent cases such as the widening current account deficit in the U.S.
} 
payments of the United States. Clausen and Kandil (2005) extend this analysis to contrast the cyclicality of the current and financial ac-counts in nine industrial countries. Kandil (2006) analyzes demand and supply factors that differentiate the allocation of exchange rate fluctuations between output growth and price inflation across samples of developing and industrial countries. Kandil (forthcoming) traces the effects of exchange rate shocks across components of aggregate demand in developing and industrial countries. This paper extends the analysis to focus on the cyclicality of the current and financial accounts with respect to exchange rate fluctuations. More specifically, the paper analyzes disaggregated evidence for channels of interaction between currency fluctua-tions and the balance of payments in a sample of developing and developed countries. Currency fluctuations determine domestic and external balances. Domestic balances are determined by capacity limitations and components of domestic and external demand. Of particular interest is to evaluate the effects of currency fluctuations on the current account balance and accompanying financial flows that are necessary to close the gap.

The paper analyzes the effects of exchange rate fluctuations and the aggregate economy in the process of forming rational expectations. Recent experiences of currency crises have brought to the forefront the importance of anchoring agents' forecasts in the design of an appropriate exchange rate policy. The theory (for details, see Kandil and Mirzaie (2002)) aims to separate the effects of anticipated shifts in the exchange rate from unanticipated deviation around agents' forecasts. Anticipated movement in the exchange rate varies with agents' observations of macroeconomic fundamentals, which determine changes in the exchange rate over time. Deviation in the realized exchange rate from its anticipated value captures the unanticipated component of the exchange rate.

Exchange rate fluctuations are assumed to be randomly distributed around a steady-state stochastic trend over time. Positive shocks to the exchange rate indicate an unanticipated increase in the foreign currency price of domestic currency-that is, unanticipated currency appreciation. Similarly, negative shocks indicate unanticipated depreciation of the exchange rate. The results clearly illustrate the different effects of anticipated and unanticipated currency movement and differentiate the effects of currency appreciation and depreciation on major components of the balance of payments in developing and industrial countries.

The data under investigation are for a sample of 21 developing countries and 25 industrial countries. The results illustrate patterns that differentiate, in general, 
between developing and industrial countries.

The remainder of the paper is organized as follows. Section II provides a theoretical background for the empirical investigation. Section III presents the empirical models. Section IV presents the empirical results. Section V concludes.

\section{A. Modelling Cyclical Effects on the Balance of Payments}

In the real world, stochastic uncertainty may arise on the demand or supply sides of the economy. Economic agents are rational. Economic fluctuations are then determined by unexpected demand and supply shocks impinging on the economic system.

The focus of the investigation is on the analysis of cyclicality in the current and financial accounts. The accounting relationship in the balance of payments indicates that a deficit in the current account may either be associated with an increase in the financial balance or a reduction in foreign reserves.

The theoretical literature suggests that the main components of the balance of payments, in particular, the current account balance, are sensitive to cyclical economic factors. Developments in the financial account, with the exception of foreign direct investment, are likely to be more random in nature and, therefore, can be reversed quickly. Short-term capital flows are often attracted to evidence of higher return, which could be cyclical in nature and, therefore, not necessarily sustainable based on underlying macroeconomic fundamentals. In contrast, the long-term nature of foreign direct investment, coupled with the difficulty to reverse these flows, necessitates a careful evaluation of underlying macroeconomic fundamentals in host countries.

The paper studies developments in both the current and financial accounts and provides an intuitive explanation for emerging patterns. The analysis focuses on fluctuations in the current account balance and two major underlying components: exports and imports. Similarly, the paper analyzes fluctuations in the financial balance and two major underlying components: net flows of direct investment and net flows of portfolio and other financial derivatives.

Determinants of domestic cyclical fluctuations in the current and financial balances include aggregate domestic demand, which is closely tied to the state of the business cycle. During a boom, output growth and price inflation increase. ${ }^{3}$ To capture fluctuations in relative prices and, in turn, competitiveness, the empirical model includes the real effective exchange rate. The energy price may determine both the current and financial accounts of industrial and developing countries 
through trade and financial investment.

The effects of the above variables on the current and financial accounts are explained as follows.

\section{B. The Current Account}

Both economic theory and the work of other researchers suggest that the current account of the balance of payments should be sensitive to domestic economic conditions. $^{4}$

Freund (2000) commented that the current account balances of most industrial countries have responded to changes in real GDP growth rates, with deficits typically widening during the expansionary part of a business cycle and contracting or becoming surpluses as real GDP growth declines. This is because investment and imports are likely to increase during an economic boom. ${ }^{5}$ Thus, we would expect a domestic boom to have a negative effect on the current account balance, raising imports of goods and services. The analysis of this paper will verify the empirical validity of this relationship.

Domestic inflation usually increases with improved domestic growth. There are two channels through which domestic inflation affects export growth: a scale factor and a relative price channel. The former channel suggests an increase in export growth with improved economic conditions and, hence, domestic price inflation. Concurrently, due to the latter effect higher price inflation decreases export competitiveness. The net effect on exports will depend on the relative strength of the scale and competitiveness channels.

\footnotetext{
${ }^{3}$ Kraay and Ventura (2002) document the impact of income fluctuations on the current account. Countries smooth their consumption by raising savings when income is high and vice versa. In the short-run, countries invest most of their savings in foreign assets. Fluctuations in savings lead to fluctuations in the current account that are equal to savings times the share of foreign assets in the country portfolio. The ability to purchase and sell foreign assets allows countries not only to smooth their consumption, but also their investment. Foreign assets and the current account absorb part of the volatility of these other macroeconomic aggregates.

${ }^{4}$ Theoretical small open economy models are rare in New Open Economy Macroeconomics. Obstfeld and Rogoff (1995) provide the starting point for the analysis. In their model, however, the current account is always in equilibrium, even in the short-run. Lane (1999) presents a small open economy model that allows for short-run current account imbalances and offers limited support for his model.

${ }^{5}$ The cyclicality of domestic investment relative to national savings is crucial to determine the cyclicality of the current account balance. In countries where domestic savings are low, boom periods do not result in a significant increase in savings. Other components of national savings, namely net foreign income and current transfers, are likely to be less dependent on domestic cyclical conditions. Hence, the cyclicality of domestic investment is likely to be more dominant in determining cyclical fluctuations in the current account balance.
} 
Higher inflation increases demand for foreign products relative to domestic products, resulting in an increase in imports. The effects of price inflation on exports and imports will determine changes in the trade balance and, in turn, the current account balance in the face of higher price inflation.

The effect of a higher energy price on the current account is likely to vary with a number of factors. For oil importing countries, imports increase in the face of a higher energy price. Nonetheless, exports may increase in response to a higher demand from oil-producing countries.

An increase in the real exchange rate, a real appreciation, is likely to decrease competitiveness, increasing imports and decreasing exports. ${ }^{6}$ An appreciation of the real effective exchange rate is expected to worsen the trade balance (by reducing exports and increasing imports) and real depreciation is expected to improve it. In the short-run, however, if the economy is highly dependent on imports, the elasticity of real imports is low, and the effects may be opposite (indicating a " $\mathrm{j}$-curve" effect of changes in the real effective exchange rate). ${ }^{7}$ As to the domestic value of the trade balance, currency depreciation gives with one hand, by lowering export prices, while taking away with the other hand, by raising import prices. If the elasticity of real imports is smaller than real exports, the increase in the nominal value of imports exceeds the increase in the nominal value of exports and exchange rate depreciation worsens the trade balance.

Exchange rate fluctuations my have, however, asymmetric effects on the trade balance. As Knetter (1989) indicated, unexpected currency depreciation and appreciation may affect the economy differently because the exit-entry decisions and price-setting behaviors of export-oriented firms may vary with the currency movements in different directions so as to avoid a reduction in their profits. Froot and Klemperer (1989) point out that the asymmetric response of stock prices to currency movements may occur owing to asymmetric pricing-to-market behavior. On the one hand, when the domestic currency appreciates, exporting firms with a

\footnotetext{
${ }^{6}$ Bergin and Sheffrin (2000) develop a testable inter-temporal model of the current account that allows for variable interest rates and exchange rates. They view these additional variables as channels through which external shocks may influence the domestic current account. In their words (p. 555), "the current account of a small open economy is likely to be affected not only by shocks to domestic output or government expenditure, but also by external shocks to the economies of large neighbors. Such external shocks should be expected to affect the domestic economy via changes in the world interest rate and the country's real exchange rate, both of which set the terms by which the small open economy can trade inter-temporally with the rest of the world." The empirical models of this paper capture the external channels through the real effective exchange rate.

${ }^{7}$ The $\mathrm{j}$-curve describes the lagged response of the quantity adjustment to a change in the currency price.
} 
market-share objective do not permit local currency prices to increase because of the risk of losing their share, so they decrease their profit margins. On the other hand, under currency depreciation, exporting firms with a market-share objective maintain rather than increase their profit margins as a result of their focus on sales volume. $^{8}$

\section{The Financial Account}

The impact of cyclical factors on the financial account of the balance of payments may be harder to predict. Given the openness of the financial account in industrial countries, financial flows in and out of these countries are driven by competitiveness. In this sense, a current account deficit accompanying a financial account surplus could be identified as signaling relatively favorable economic conditions in a country. This would contrast the perspective of a current account surplus signaling competitiveness.

In developing countries, fluctuations in the financial account are likely to be mostly driven by fluctuations in FDI flows, as well as private and public financial flows. While domestic cyclical conditions determine inflows and outflows of FDI and private financial flows, management of public debt may be a key component of other financial flows.

Higher domestic growth in one country, compared to its competitors, is likely to increase foreign direct investment and financial inflows. The financial balance is likely to improve in response to better economic conditions in the domestic economy. Good investment opportunities attract financial inflows, which then provide the necessary savings to fund investment and, thereby, contribute to higher growth. Therefore, an improvement in the financial account balance is associated with higher GDP growth and/or price inflation (an economic boom). Hence, domestic growth matters to the relative financial position of a given country compared to other financial competitors. Higher energy prices may be consistent with an increase in financial inflows to industrial countries from oil-producing countries, resulting in an improved financial balance.

An increase in the real effective exchange rate may improve or worsen the

\footnotetext{
${ }^{8}$ Other studies that support the same arguments are Marston (1990) and Goldberg (1995). Another explanation of the asymmetric effect of exchange rate fluctuations is proposed by Baldwin and Krugman (1989) and Dixit (1989). They argue that new export competitors enter the market during depreciation periods. However, these competitors remain in the market when the currency appreciates (hysteretic behavior).
} 
financial balance. ${ }^{9}$ An ap-preciation of the exchange rate may signal the strength of the domestic economy, which further increases net financial inflows. Alternatively, an appreciation decreases the relative value of financial inflows in do-mestic currency while increasing the relative value of financial outflows in foreign currency. This scenario is consistent with a reduction in net financial inflows.

\section{Empirical Models}

The empirical investigation analyzes annual time-series data of each of the current account and financial account balances and major underlying components: exports, imports, the trade balance, net capital flows, and net FDI flows. The sample of countries includes 21 developing and 25 developed countries. The sample period for investigation is 1971-2000. Data description and sources are provided in Appendix B.

Over time, it is assumed that macroeconomic variables fluctuate in response to aggregate domestic demand shocks, energy price shocks, and exchange rate shocks. Shocks are randomly distributed over the time span under investigation. The real effective exchange rate is constructed as a weighted average of the real exchange rate of the domestic currency relative to the currency of each major trading partner with weights that measure the share of the trading partner in total trade. Accordingly, the empirical investigation will combine the nominal exchange rate policy with movements in domestic price inflation relative to that of major trading partners to determine the implications of fluctuations in the real exchange rate on components of the current and financial balances in a sample of developing and developed countries.

Exchange rate shocks are distributed around an anticipated stochastic steadystate trend. This trend varies with agents' observations of macroeconomic fundamentals that are likely to determine the exchange rate. Over the time span under investigation, exchange rate shocks occur with equal probability and follow a symmetric distribution. Shocks are deviations around the stochastic moving trend over time. These deviations arise regardless of the exchange rate system. Under a flexible exchange rate system, movements in the exchange rate may respond to trade or financial shocks that arise unexpectedly. Under a fixed exchange rate system, agents may adjust their forecasts of the exchange rate based on

${ }^{9}$ At the same time, one could argue that net financial inflows cause a real appreciation. 
macroeconomic fundamentals. For example, external imbalance may lead agents to perceive the fixed exchange rate to be overvalued as they anticipate a high risk of devaluation. Shocks would measure, therefore, deviation in the forecasted exchange rate from its prevailing fixed value.

The estimated equation is as follows:

$$
\begin{aligned}
D_{y t}= & A_{0}+A_{1} E_{t-1} D_{z t}+A_{2}\left(D_{z t}-E_{t-1} D_{z t}\right)+A_{3} E_{t-1} D_{n t}+A_{4}\left(D_{n t}-E_{t-1} D_{n t}\right) \\
& +A_{7} E_{t-1} D_{s t}+\mathrm{A}_{8 \mathrm{p}} \text { poss }_{t}+\mathrm{A}_{8 \mathrm{n}} n e g s_{t}+v_{t}
\end{aligned}
$$

Test results are consistent with non-stationary dependent variables. ${ }^{10}$ Given nonstationarity test results, the empirical models are specified in first-difference form where $D($.$) is the first-difference operator. { }^{11}$ Let $y_{t}$ be the value of each of the dependent variables: log imports (imp), log exports (exp), the value of the trade balance (tbal), the value of the current account balance (CA), the value of net capital flows (capflo), ${ }^{12}$ the value of net foreign direct investment (FDI), and the value of the financial account balance (FAC). Explanatory variables in the model include the energy price, nominal GDP, and the exchange rate, as explained below. ${ }^{13}$ The unexplained residual of the model is denoted by $V_{t}^{y}$.

Let $z_{t}$ be the log value of the energy price. Agents' expectations of a variable at time $t$ based on information available at time $t-1$ is denoted by $E_{t-1}$. The impact of energy price shifts is likely to vary depending on the country's need to import oil. For oil-importing countries, an increase in the energy price (both anticipated and unanticipated) is likely to decrease output and income. Consequently, there will be a reduction in exports and a worsening of the trade balance, and possibly the current account balance. For oil-exporting countries, an increase in the energy price is likely to increase output, income and, therefore, domestic spending. It is likely that imports will increase with the increase in oil exports. The net effect on the trade balance and the current account balance will depend on relative adjustments in exports and imports.

\footnotetext{
${ }^{10}$ For details, see Kwiatkowski et. al. (1992). Non-stationarity indicates that the series follows a random walk process. Upon first-differencing, the resulting series are stationary, providing the domain for demand and supply shocks as specified in theory.

${ }^{11}$ Given non-stationarity of the estimated dependent variables, the empirical models are estimated in firstdifference form. Hence, the anticipated component measures anticipated change in the policy variable. Shocks approximate unanticipated change in the policy variable.

${ }^{12}$ This is measured by net flows of portfolio and other financial derivatives.

${ }^{13}$ Following tests of non-stationarity of the energy price, nominal GDP and the exchange rate, there is no evidence of cointegration between the non-stationary dependent variables and non-stationary independent variables. Hence, the empirical models are estimated without an error correction term.
} 
Fluctuations in the oil price may also result in fluctuations in the financial balance. The accumulation of the oil wealth in oil-exporting countries may result in an increase in net FDI flows to invest in the oil sector and other sectors of the economy. Nonetheless, the increase in foreign reserves with the increase in oil exports is likely to increase financial outflows to maximize on the return of these reserves beyond the absorption capacity of the domestic economy. In oil-importing countries, it is less clear to predict the impact of an increase in the oil price on financial and FDI flows. As oil imports increase, a worsening of the current account balance may necessitate a higher need for external borrowing, resulting in an increase in financial, and possibly FDI net flows.

Nominal GDP approximates aggregate domestic demand where $n_{\mathrm{t}}$ denotes its $\log$ value. ${ }^{14}$ Both an-ticipated and unanticipated demand-side stabilization policies stimulate aggregate demand and economic activity. ${ }^{15}$ As a result, there is an increase in domestic demand and maybe external demand (exports). As income increases, the demand for imports increases as well. The net effect on the trade and, in turn, the current account balance will depend on the relative increase in exports and imports. The positive effect of domestic policies on economic activity maybe stimulating of FDI and other portfolio financial inflows. Anticipated appreciation of the real effective exchange rate determines the cost of the output supplied. Let $s_{\mathrm{t}}$ be the log value of the real effective exchange rate. An increase in the exchange rate indicates real appreciation of the domestic currency. As producers anticipate a lower cost of imported intermediate goods, in the face of currency appreciation, they increase the output supplied. Accordingly, anticipated appreciation of the exchange rate may stimulate an increase in spending on imports. The increase in output supply may further stimulate an increase in export growth. The relative increase in exports and imports will determine the effect of anticipated currency appreciation on the trade balance and, in turn, the current account balance. Improvement in the output supply may stimulate an increase in FDI and portfolio financial inflows.

\footnotetext{
${ }^{14}$ Nominal GDP is likely to vary with a variety of shocks that underlie aggregate demand: the money supply, government spending, velocity, consumption, investment, and external shocks. Moreover, nominal GDP growth captures real growth and price inflation. Both channels are important to the cyclicality of the current and financial accounts. In a separate experiment, two policy measures, government spending and the money supply, approximate aggregate domestic demand. Results are available upon request.

${ }^{15}$ In the real world, institutional rigidity may interfere with agents' ability to adjust fully to anticipated demand shifts. Institutional rigidity may be attributed to wage and/or price rigidity. For a discussion of the implications of sticky-wage and sticky-price models, see Kandil (1996).
} 
Unanticipated change in the exchange rate is likely, however, to determine both aggregate demand and supply. A positive shock to the exchange rate, poss $s_{\mathrm{t}}$, indicates currency appreciation, whereas a negative shock, $n e g s_{t}$, indicates depreciation. Unanticipated currency appreciation decreases the cost of buying intermediate goods, increasing the output supplied. Concurrently, appreciation decreases net exports. The effects of unanticipated currency appreciation are likely to depend on the relative effects of supply and demand channels on output growth. If the reduction in net exports dominates output growth decreases and, therefore, income. The reduction in income decreases spending on imports. The net effect on the trade balance and, in turn, the current account balance will depend on the relative change in exports and imports. Accompanying effects on FDI and financial flows will depend on the relative expansionary and contractionary effects of unanticipated currency appreciation on the economy.

\section{Empirical Results}

All variables are measured in dollar value. Data description and sources are described in Appendix B.

\section{A. A Summary of the Time-Series Evidence}

The empirical model in (1) is estimated jointly with equations that describe agents' forecasts of explanatory variables that enter the model. Appendix B describes in details the econometric methodology. The results of estimating the empirical model that explains trade components (exports and imports), and the current account balance are presented in Tables A1 and A2 of the appendix for the samples of developing and industrial countries. Given the focus of the paper to evaluate the effects of exchange rate shocks, the tables summarize the parameters that measure the response of each of the current account components under investigation to unanticipated, positive and negative, exchange rate fluctuations. ${ }^{16}$ The exchange rate is measured by the real effective exchange rate. A positive shock to the exchange rate indicates currency appreciation, while a negative shock indicates depreciation.

Exchange rate appreciation (depreciation) decreases (increases) competitiveness and the volume of ex-ports. On the other hand, exchange rate appreciation

\footnotetext{
${ }^{16}$ Detailed results are available upon request.
} 
(depreciation) decreases (increases) the cost of im-ported inputs and increases (decreases) the output supply. This channel may stimulate an increase (a decrease) in export growth.

The bulk of the evidence, in developing and industrial countries, supports inelastic export demand. Exchange rate depreciation does not stimulate an increase in demand and, in turn, the value of exports. Similarly, appreciation increases the value of exports, indicating inelastic adjustment of the export volume, within a year, to changes in prices in response to exchange rate fluctuations.

Currency appreciation (depreciation) is likely to decrease (increase) the cost of imports. If the demand for imports is elastic, the volume and, in turn, the dollar value of imports increases (decreases).

The evidence across developing countries indicates the inelastic response of imports to currency appre-ciation. The insignificant response indicates that currency appreciation does not provide an incentive to increase imports absent growth incentives. In contrast, constraints appear to be binding regarding the cost of imports. Accordingly, imports decrease as the cost of imports increases in the face of currency depreciation in many developing countries.

In contrast, the evidence across industrial countries does not differentiate imports' elasticity pronouncedly with respect to currency appreciation and depreciation. The volume of imports appears to be sufficiently elastic to adjust positively to currency fluctuations (both appreciation and depreciation) in a few industrial countries. Elasticity in the face of currency appreciation indicates capacity to utilize imports and expand output. Elasticity in the face of currency depreciation indicates low dependency on imports in industrial countries.

The above evidence indicates inelastic demand for exports with respect to currency appreciation and depreciation. The dollar value of exports appears to be increasing (decreasing) with currency appreciation (depreciation) in many industrial and developing countries. Imports appear more elastic in the face of currency appreciation in industrial countries, compared to developing countries, increasing the value of imports. Imports are also elastic with respect to currency depreciation, decreasing in developing and industrial coun-tries. The combined effects on the trade balance will be dependent on the relative increase in exports and imports.

The combined evidence does not reveal the importance of currency fluctuations to the trade balance in developing countries. This evidence indicates failure of developing countries to capitalize on improved com-petitiveness with respect to 
exchange rate depreciation. Given depreciation, the value of exports decreases in dollar value. Concurrently, depreciation increases the cost of imported goods, necessitating a reduction in imports. Both channels appear to cancel out in many developing countries.

In general, the effects of currency fluctuations on imports and exports cancel out in industrial countries. In a few cases, the effects of currency appreciation (depreciation) in improving (deteriorating) the trade balance is consistent with an increase (decrease) in the dollar value of exports that dominates the increase (decrease) in the dollar value of imports. The improvement in the trade balance indicates that loss of competitiveness is more than offset via appreciation in national currency relative to the dollar. Similarly, the deterioration indicates that improved competitiveness is more than offset via depreciation in national currency relative to the dollar.

The composite evidence provides some support for improvement in the current account balance with currency depreciation in a sample of developing and industrial countries. Despite insignificant effects of currency depreciation on the trade balance, depreciation appears to have a net positive effect on the income balance and net transfers and, therefore, improve the current account balance in a few countries, both developing and industrial countries.

The results of estimating the empirical models that explain the financial account balance and its under-lying components, net flows of direct investment and net flows of portfolio and other financial derivatives, are presented in Tables A3 and A4 of the appendix. To conserve space, the tables summarize estimates of parameters that measure the response of components of the financial balance to positive and negative exchange rate shocks.

Fluctuations in capital flows appear, in general, to be random in many developing and industrial countries with limited evidence regarding systematic correlation with exchange rate fluctuations. Currency apprecia-tion increases the cost of foreign direct investment, which is consistent with a reduction in net FDI flows in a few countries. In a few other cases, currency depreciation decreases returns on FDI, which has a depressing effect on these flows.

The bulk of the evidence differentiates between the effects of currency depreciation in developing and industrial countries. Currency depreciation increases the risk of financial investment, deteriorating the financial balance, in developing countries. In contrast, currency depreciation in industrial countries may provide support for financial inflows as the cost of foreign investment decreases. 


\section{B. Cross-Section Analysis}

To further understand the time-series estimates, this section summarizes crosscountry correlations between the time-series responses to currency fluctuations.

\section{(1) Correlations across Developing Countries with Respect to Currency Appreciation}

Table 1 presents correlations between the variables' responses to a positive exchange rate shock (apprecia-tion). Currency appreciation increases both export and import values, as evident by the positive correlation coefficient, 0.47 . Currency appreciation increases imports and deteriorates the current account balance, as evident by the negative correlation coefficient, -0.53 . An increase in imports with respect to currency appre-ciation correlates with an increase in FDI inflows, as evident by the positive correlation coefficient 0.45 . A deterioration in the current account balance correlates with an increase in net FDI flows and the financial account balance, as evident by the negative correlations, $-0.41,-0.63$. The evidence indicates the adverse effects of currency appreciation on the trade balance and, in turn, the current account balance in developing countries. Deterioration in the current account balance necessitates additional financing.

\section{(2) Correlations across Developing Countries with Respect to Currency Depreciation}

Table 2 presents correlations between the variables' responses to a negative exchange rate shock (depre-ciation). Currency depreciation decreases export growth and deteriorates the current account balance, as evident by the positive correlation coefficient, 0.73 . The reduction in exports correlates with an increase in net capital flows, FDI flows and the financial balance with correlations - 0.60 , 0.53 , and -0.70 , respectively.

In contrast, currency depreciation increases the dollar value of imports and deteriorates the current account balance. This is evident by the negative correlation coefficient, -0.68 . The increase in imports correlates with an increase in net capital flows and the net financial balance, as evident by the positive correlation coefficients, 0.70 , and 0.71 .

The combined effects of a reduction in exports and an increase in imports result in a reduction in the current account balance that correlates with an increase in net capital flows, net FDI flows and the financial account balance in the face of currency depreciation. This is evident by the negative correlation coefficients, $0.79,-0.67$, and -0.99 , respectively. The increase in net capital flows and FDI flows 
correlate with an improvement in the financial balance, as evident by the positive correlation coefficients, 0.76 and 0.71 .

The evidence indicates the adverse effects of currency depreciation on the current account balance in developing countries. Absent measures to stimulate export growth and given the high dependency on imports, the current account balance deteriorates with currency depreciation. Deterioration in the current account balance necessitates additional financing.

\section{(3) Correlations across Industrial Countries with Respect to Currency Appreciation}

Currency appreciation increases the nominal value of exports and imports, with a correlation coefficient, 0.90 . Higher exports and imports correlate with an increase in FDI flows, as evident by the positive correlation coefficients, 0.59 and 0.58. Fluctuations in both exports and imports are not significantly correlated with changes in the trade or the current account balance with respect to exchange rate movement. It appears, therefore, that fluctuations in exports and imports cancel out. An improvement (deterioration) in the trade balance determines changes in the current account balance with a correlation coefficient 0.95 . Changes in the trade balance also determine changes in net capital flows and the financial balance. An improvement (deterioration) in the current account balance correlates with a reduction (increase) in net capital flows and the financial balance, as evident by the negative correlation coefficients, -0.51 and -0.53 . Similarly, an improvement (deterioration) in the current account balance correlates with a decrease (increase) in net capital flows and the financial balance with correlation coefficients -0.65 and -0.70 , respectively. An increase in each of net capital flows and FDI flows correlates with an increase in the financial account balance, as evident by the positive correlation coefficients, 0.90 and 0.36 .

Three factors differentiate correlations with respect to currency appreciation across industrial and devel-oping countries: (i) The increase in imports dominates the reduction in the current account balance with respect to currency appreciation in developing countries, (ii) the trade balance is an important determinant of fluctuations in the current account balance with respect to currency appreciation in industrial countries, (iii) FDI flows are an important determinant of financing a deteriorating current account balance in develop-ing countries. In contrast, portfolio flows are an important determinant of financing a deteriorating current account balance in industrial countries. 


\section{(4) Correlation across Industrial Countries with Respect to Currency Depreciation}

The reduction in the value of exports correlates with a reduction in the value of imports, as evident by the positive correlation coefficient 0.80 . Neither factor is dominantly correlated with the trade or the current account balance. Both the trade and current account balances correlate positively with a coefficient 0.97 .

Depending on which channel dominates (the export or import channels), an improvement (deterioration) of the trade balance correlates with a deterioration (improvement) in net capital flows and net financial balances, as evident by the negative correlation coefficients, -0.86 and -0.53 . Similarly, an improvement (deterioration) of the current account balance correlates with a deterioration (improvement) in net capital flows, net FDI flows, and net financial balance. This is evident by the negative correlation coefficients, $-0.84,-0.36$, and -0.42 . Movements in the capital and financial accounts are closely correlated, as evident by the positive correlation coefficient, 0.71 .

Three factors differentiate correlations with respect to currency depreciation across industrial and devel-oping countries: (i) The increase in imports dominates the reduction in the current account balance with respect to currency depreciation in developing countries, (ii) the trade balance is an important determinant of fluctuations in the current account balance with respect to currency depreciation in industrial countries, (iii) FDI flows are an important determinant of financing a deteriorating current account balance and, therefore, correlates significantly with the financial balance in developing countries.

\section{(5) An Assessment}

In general, imports appear more elastic to changes in the exchange rate in industrial countries, compared to developing countries, in the face of both currency appreciation and depreciation. Currency appreciation increases imports in industrial countries while currency depreciation decreases demand for imports. Given that the demand for exports is generally inelastic, elastic demand for imports determines the direction of changes in the trade and current account balances in many industrial countries. Adjustments of imports to exchange rate fluctuations are inelastic in developing countries. Accordingly, appreciation (depreciation) does not increase (decrease) demand for imports. Given that exports do not appear elastic with respect to currency fluctuations, the impact of these fluctuations, via adjustments in imports, is more important to the trade and current account balances in developing countries compared to industrial countries. 


\section{Summary and Conclusions}

The analysis of this paper has focused on the effects of exchange rate fluctuations on major components of the balance of payments in a sample of industrial and developing countries. Recent waves of currency crises have brought to the forefront the discussion about the appropriate exchange rate system and the effects of currency fluctuations on the macroeconomy.

Using a rational-expectation model, agents engage in a process of forming their forecasts about the exchange rate using their observations of macroeconomic fundamentals. Deviations in the exchange rate from agents' forecasts may arise under fixed or flexible exchange rate systems. Under a flexible system, the exchange rate moves unexpectedly in response to market developments that determine flows in the financial and current accounts. Alternatively, agents may adjust their forecasts under a fixed exchange rate system, deviating from the observed exchange rate.

The analysis of this paper presents evidence on the difference between the effects of unanticipated currency appreciation and depreciation on major components of the trade balance, the current account balance, and the financial balance across a sample of developing and industrial countries.

The data under investigation include a sample of 21 developing countries and 25 industrial countries over the sample period 1971-2000. An appreciation of the real effective exchange rate is expected to worsen the trade balance (by reducing exports and increasing imports) and real depreciation is expected to improve it. In the short-run (one year according to data frequency), elasticity of imports and exports determines the effects of exchange rate fluctuations on the trade balance. The response of exports to changes in the exchange rate is dependent on the elasticity of foreign demand with respect to changes in the exchange rate.

If demand is inelastic, currency appreciation (depreciation) may lead to an increase (a decrease) in the dollar value of exports. Similarly, in the short-run, if the economy is highly dependent on imports, the elasticity of imports is low and the effects of depreciation maybe opposite, increasing the value of imports in support of a J-curve effect. As to the value of the trade balance, currency depreciation gives with one hand, by lowering export prices, while taking away with the other hand, by raising import prices. If imports are elastic and exports are inelastic the reduction in the dollar value of imports will be matched with a reduction in the dollar value of exports. The direction of changes in the trade balance will be 
dependent on relative changes in exports and imports.

As to the effects of exchange rate fluctuations on the current account balance, the result will be dependent on the change in the trade balance and corresponding changes in the income and transfer balances of the current account with respect to exchange rate fluctuations. A depreciation of the exchange rate may stimulate an increase in remittances and transfer inflows and decrease outflows, improving the current account balance.

An increase in the real effective exchange rate may improve or worsen the financial balance. An appre-ciation of the exchange rate may signal the strength of the domestic economy, which further increases net financial inflows. Alternatively, an appreciation decreases the relative value of financial inflows in domes-tic currency, while increasing the relative value of financial outflows in foreign currency. This scenario is consistent with a reduction in net financial inflows.

The evidence across developing countries, in general, appears to be supportive of the positive response of export growth to currency appreciation and depreciation. Hence, the effect of exchange rate fluctuations on export competitiveness appears to be limited in developing countries. Accordingly, exchange rate apprecia-tion (depreciation) increases (decreases) the dollar value of exports, dominating the change in quantity. The bulk of the evidence in industrial countries also supports inelastic export demand. Exchange rate depreci-ation does not stimulate an increase in demand and, in turn, the value of exports. Similarly, appreciation increases the value of exports, indicating inelastic adjustment, within a year, to changes in prices in response to exchange rate fluctuations.

Across developing countries, currency appreciation does not provide an incentive to increase imports absent growth incentives. Constraints appear, however, to be binding regarding the cost of imports. Accordingly, imports decrease as the cost of imports increases in the face of currency depreciation in many developing countries. The evidence across industrial countries does not differentiate imports' elasticity pro-nouncedly with respect to currency appreciation and depreciation. The volume of imports appears to be sufficiently elastic to adjust positively to currency fluctuations (both appreciation and depreciation) in a few industrial countries. Elasticity in the face of currency appreciation indicates capacity to utilize imports and expand output. Elasticity in the face of currency depreciation indicates low dependency on imports in industrial countries.

The evidence does not indicate the importance of currency fluctuations to the trade balance in developing countries. Currency appreciation does not increase 
exports or imports significantly in many developing countries. In contrast, where significant, currency depreciation decreases both export and import growth.

This evidence indicates failure of developing countries to capitalize on improved competitiveness with respect to exchange rate depreciation. Given depreciation, the dollar value of exports decreases. Concurrently, depreciation increases the cost of imports, decreasing the value of imports. Both channels appear to cancel out in many developing countries.

In general, the effects of currency fluctuations on imports and exports cancel out in industrial countries. In a few cases, the effects of currency appreciation in improving the trade balance is consistent with an increase in the dollar value of exports that dominates the increase in the dollar value of imports. Such an improvement indicates that loss of competitiveness is more than offset via the appreciation in national currency relative to the dollar.

Across developing and industrial countries, currency appreciation does not seem to matter much or yield significant results on the current account balance. In contrast, the evidence provides a stronger support for an improvement in the current account balance with currency depreciation in many developing and industrial countries.

Fluctuations in capital flows appear, in general, to be random in many developing and industrial countries, with limited evidence regarding systematic correlation with exchange rate fluctuations. Across developing and industrial countries, the effects of currency fluctuations appear to be mixed on FDI flows. Currency appreciation increases the cost of FDI, which is consistent with a reduction in net FDI flows in a few countries. In a few other cases, currency depreciation decreases returns on FDI, which has a depressing effect on these flows.

Fluctuations in the exchange rate are an important determinant of the financial balance in developing countries. Currency depreciation signals concerns about the stability of underlying macroeconomic funda-mentals, resulting in a reduction in financial inflows and an increase in outflows and, therefore, a worsening of the financial balance. In contrast, currency depreciation in industrial countries may provide support for financial inflows as the cost of foreign investment decreases.

The combined evidence discounts the value of exchange rate policy to competitiveness and, therefore, export growth in many developing and industrial countries. Exchange rate depreciation is relatively more important to reduce dependency on imports in industrial countries, compared to developing countries. 


\begin{abstract}
Absent measures to stimulate export growth and given the high dependency on imports, the current account balance deteriorates with respect to currency depreciation in developing countries. Deterioration in the current account balance necessitates additional financing. In contrast, the reduction in the value of exports correlates with a reduction in the value of imports in industrial countries. Neither factor is dominantly correlated with the trade or the current account balance. Currency appreciation increases imports and deteriorates the current account balance in developing countries. A deterioration in the current account balance correlates with an increase in net FDI flows and the financial account balance across developing countries. Across industrial countries, currency appreciation increases the nominal value of exports and imports. The trade and, in turn, the current account balance may improve or deteriorate, as a result.

In sum, the evidence provides support for the effectiveness of currency depreciation in curbing import growth across industrial countries. Moreover, currency depreciation increases net financial flows to industrial countries. Such an evidence argues for the benefits of a flexible exchange rate system, prevailing in many industrial countries, to ensure that a depreciating rate curbs import growth and increases financial flows. Appreciation appears to have a limited adverse effect in industrial countries. In developing countries, where many countries have been following a managed fixed exchange rate system, the evidence indicates the adverse effect of an overvalued exchange rate. The devastating effects of abandoning a peg could be even more pronounced if it results in a severe unanticipated devaluation in the value of domestic currency.
\end{abstract}

\title{
Acknowledgements
}

The author thanks an anonymous referee for helpful comments. The views in the paper are those of the author and should not be interpreted as those of the International Monetary Fund.

Received 12 October 2006, Revised 26 March 2007, Accepted 3 July 2008 


\section{Appendix}

\section{A. Econometric Methodology}

The surprise terms that enter the empirical model (1) are unobservable, necessitating the construction of empirical proxies before estimation takes place. Thus, the empirical models include equations that describe agents' forecast of aggregate (nominal GDP), the change in energy price, and the change in the real effective exchange rate. All variables are first-differenced to render the series stationary.

To decide on variables in the forecast equations, a formal causality test is followed. Each variable is regressed on two of its lags as well as two lags of all variables that enter the model: the change in the log value of the energy price, nominal GDP, the real exchange rate, government spending, and the money supply. The joint significance of the lags is tested for each variable. Accordingly, the forecast equations account for the lags of variables proven to be statistically significant.

Subtracting the above forecasts from the actual change in the variable results in surprises that enter the empirical model. In order to obtain efficient estimates and ensure correct inferences (i.e., to obtain consistent variance estimates), the empirical model is estimated jointly with a forecast equation for each anticipated regressor, following the suggestions of Pagan (1984 and 1986). To account for endogenous variables, instrumental variables are used in the estimation of the empirical models. The instrument list includes two lags of price, 5 lags of the energy price, 5 lags of the real exchange rate, 5 lags of the money supply, and 5 lags of government spending. The paper's evidence remains robust with respect to modifications that alter variables or the lag length in the forecast equations and/or the instruments list.

Following the suggestions of Engle (1982), the results of the test for serial correlation in simultaneous equation models are consistent with the presence of first-order autoregressive errors for some countries. To maintain comparability, it is assumed in all models that the error term follows an AR(1) process. The estimated models are transformed, therefore, to eliminate any possibility of serial correlation. The estimated residuals from the transformed models have zero means and are serially independent. 


\section{B. Data Sources}

The sample period for investigation is 1971-2000. Annual data for the developing and industrial countries are described as follows:

1. Real Output: Real output of GDP measured in terms of 1982 dollars.

2. The Price Level: The deflator for GDP.

3. The Energy Price: The price of Saudi Arabia oil.

4. Government Spending: Nominal values of all payments by the government.

5. Money Supply: the sum of currency plus demand deposits.

6. Real Exchange Rate: The real price of the domestic currency in terms of currencies of major trading partners.

7. Aggregate Demand: The nominal value of GDP.

8. Consumption, Investment, Exports, and Imports: Nominal values of expenditure components in the national income account.

9. Data of the Balance of Payments: exports and imports of goods and services, trade balance of goods and services, net capital flows, net foreign direct investment, and financial balance.

Sources: 1 through 8 are taken from the World Economic Outlook databank, and source 9 is taken from Balance of Payment Statistics available from the International Monetary Fund, Washington, D.C. 


\section{References}

Arora, Vivek, Steven Dunaway, and Hamid Faruqee(2001), "Sustainability of US External Current Ac-count Deficit", in the United States: Selected Issues, IMF Country Report 01/149 (Washington: Inter-national Monetary Fund, August), pp. 25-39.

Bergin, R. Paul and Steven M. Sheffrin(2000) "Interest Rates, Exchange Rates, and Present Value Models of the Current Account", The Economic Journal, 110 (463), pp. 535-558.

Cooper, Richard N.(2001), “The US Current Account: Is It Sustainable? Will It Be Sustained?", Brookings Papers on Economic Activity, 0(1), pp. 217-26.

Clausen, R. Jens and Magda Kandil(2005), "On the Cyclicality in the Current and Financial Accounts: Evidence from Nine Industrial Countries", IMF Working Paper No. 05/56 (Washington:International Monetary Fund).

Freund, Caroline L.(2000), "Current Account Adjustment in Industrial Countries", Unpublished, Inter-national Finance Discussion, Paper No. 692 (Washington: Board of Governors of the Federal Reserve System).

Badwin, R. and P. Krugman(1989), "Persistent Trade Effects of Large Exchange Rate Shocks", Quarterly Review of Economics, 104:635-654.

Dixit, A.(1989), "Hysteresis, Import Penetration, and Exchange Rate Pass-Through", Quarterly Journal of Economics, 54:205-227.

Engle, R. R.(1982), "A General Approach to Lagrange Multiplier Model Diagnostics", Journal of Econometrics, 20, 83-104.

Froot, K. A. and P. D. Klemperer(1989), "Exchange Rate Pass-through When Market Share Matters", American Economic Review, 79:637-654.

Goldberg, P. K.(1995), "Product Differentiation and Oligopoly in International Markets: The Case of the U.S. Automobile Industry", Econometrica, 63:891-951.

International Monetary Fund(1993), "Balance of Payments Manual", Fifth Edition, reprinted 1997, Washington D.C.

Kandil, Magda(1996), "Sticky Wage or Sticky Price? Analysis of the Cyclical Behavior of the Real Wage", Southern Economic Journal, October, pp. 440-459.

Kandil, Magda(2000), "The Asymmetric Effects of Exchange Rate Fluctuations: Theory and Evidence from Developing Countries", IMF Working Paper, WP/00/184.

Kandil, Magda(2006), "On the Transmission of Exchange Rate Fluctuations: Theory and Evidence from Developing Countries", The Journal of International Trade and Economic Development, 15(1), March pp. 101-127.

Kandil, Magda, "Exchange Rate Fluctuations and the Macroeconomy: Channels of Interaction in De-veloping and Developed Countries", Eastern Economic Journal, (forthcoming).

Kandil, Magda and Joshua Greene(2002), "The Impact of Cyclical Factors on the US Balance of Pay-ments", IMF Working Paper No. 02/45 (Washington: International Monetary Fund). 
Kandil, Magda and Ida Mirzaie(2002), "Exchange Rate Fluctuations and Disaggregated Economic Activity in the U.S.: Theory and Evidence", Journal of International Money and Finance, February, No. 1, pp. 1-31.

Knetter, M. M(1989), "Price Discrimination by U.S. and German Exporters", American Economic Review, 79, pp. 198-210.

Kraay, Aart and Jaume Ventura(2002), "Current Accounts in the Long and Short Run", NBER Working Paper No. 9030.

Kwiatkowski, Denis, Peter C. B. Phillips, Peter Schmidt, and Yongcheol Shin(1992), "Testing the Null Hy-pothesis of Stationarity Against the Alternative of a Unit Root: How Sure Are We That Economic Time Series Have a Unit Root?", Journal of Econometrics, Vol. 54, pp. 159-78.

Lane, Philip(1999), "Money Shocks and the Current Account", mimeo, Trinity College. Marston, R. C.(1990), "Pricing to Market in Japanese Manufacturing", Journal of International Economics, Vol. 29, pp. 217-236.

McKinnon, Ronald, "The International Dollar Standard and Sustainability of the U.S.", Brookings Papers on Economic Activity, O (1), pp. 227-39.

Obstfeld,Maurice and Kenneth Rogoff(1995), "Exchange Rate Dynamics Redux", Journal of Political Econ-omy, 103 (3), pp. 620-60.

Pagan, Adrian(1984), "Econometric Issues in the Analysis of Regressions with Generated Regressor", Inter-national Economic Review, Vol. 25, 221-47.

Pagan, Adrian(1986), "Two Stage and Related Estimators and Their Applications", Review of Economic Studies, Vol. 53, 517-38. 